Meta

Journal des traducteurs

Translators' Journal

\title{
Proactive Translatology vis a vis Advertising Messages
}

\section{María Calzada Pérez}

Volume 50, numéro 4, décembre 2005

Pour une traductologie proactive - Actes

For a Proactive Translatology — Proceedings

Por una traductología proactiva - Actas

URI : https://id.erudit.org/iderudit/019912ar

DOI : https://doi.org/10.7202/019912ar

Aller au sommaire du numéro

Éditeur(s)

Les Presses de l'Université de Montréal

ISSN

0026-0452 (imprimé)

1492-1421 (numérique)

Découvrir la revue

Citer cet article

Calzada Pérez, M. (2005). Proactive Translatology vis a vis Advertising

Messages. Meta, 50(4). https://doi.org/10.7202/019912ar

\section{Résumé de l'article}

Beaucoup d'études de qualité portant sur la traduction se sont concentrées sur le texte verbal. Néanmoins, dans notre monde postmoderne, la multimodalité est exploitée au maximum, comme en témoigne la publicité. D’autre part, l'hypertextualité est aussi une caractéristique des messages publicitaires d'aujourd'hui. En outre, la multimodalité et l'hypertextualité sont idéologiquement conçues non seulement pour vendre des produits mais aussi pour promouvoir de nouveaux styles vie. Dans la première section, cette étude recourt à Van Leeuwen (1993), Gastil (1992) et Kress et Van Leeuwen (1998) pour cerner la notion de multimodalité. Il utilise aussi Askehave et Nielsen (2004) pour étudier l'hypertextualité en général et les relations structurelles/associatives en particulier. Ces propositions théoriques sont appliquées par la suite (dans les sections 3 et 4) sur quatre publicités traduites (ou en rapport avec la traduction) en format papier et/ou en format électronique. Finalement, la section 5 propose une série de conclusions en rapport avec les sujets en discussion, reliées aux conséquences idéologiques du travail de traduction (ou en rapport avec la traduction).
Ce document est protégé par la loi sur le droit d'auteur. L’utilisation des services d’Érudit (y compris la reproduction) est assujettie à sa politique d'utilisation que vous pouvez consulter en ligne.

https://apropos.erudit.org/fr/usagers/politique-dutilisation/ 


\title{
Proactive Translatology vis a vis Advertising Messages
}

\author{
MARÍA CALZADA PÉREZ, \\ Universitat Jaume I, Castelló , Spain \\ uji00852@uji.infomail.es
}

\begin{abstract}
RÉSUMÉ
Beaucoup d'études de qualité portant sur la traduction se sont concentrées sur le texte verbal. Néanmoins, dans notre monde postmoderne, la multimodalité est exploitée au maximum, comme en témoigne la publicité. D'autre part, l'hypertextualité est aussi une caractéristique des messages publicitaires d'aujourd'hui. En outre, la multimodalité et l'hypertextualité sont idéologiquement conçues non seulement pour vendre des produits mais aussi pour promouvoir de nouveaux styles vie. Dans la première section, cette étude recourt à Van Leeuwen (1993), Gastil (1992) et Kress et Van Leeuwen (1998) pour cerner la notion de multimodalité. Il utilise aussi Askehave et Nielsen (2004) pour étudier l'hypertextualité en général et les relations structurelles/associatives en particulier. Ces propositions théoriques sont appliquées par la suite (dans les sections 3 et 4) sur quatre publicités traduites (ou en rapport avec la traduction) en format papier et/ou en format électronique. Finalement, la section 5 propose une série de conclusions en rapport avec les sujets en discussion, reliées aux conséquences idéologiques du travail de traduction (ou en rapport avec la traduction).
\end{abstract}

\begin{abstract}
Much good work on Translation Studies (TS) has concentrated on the verbal text. Nevertheless, in our post-modern world, multi-modality is exploited to the maximum, as advertising shows. In turn, hyper-textuality is also a common feature of today's advertising messages. Furthermore, both multi-modality and hyper-textuality are ideologically designed not only to sell products but to promote entire ways of life. In its second section, the present paper draws on Van Leeuwen (1993), Gastil (1992) and Kress and Van Leeuwen (1998) to approach the notion of multi-modality. It also draws on Askehave and Nielsen (2004) to study hyper-textuality in general and structural/associative links in particular. These theoretical proposals are then applied (in sections 3 and 4) to four translated or translation-related ads on paper and/or on electronic format. Finally, section 5 puts forward a series of conclusions related to the topics under discussion, which are connected to the ideological consequences of the translating (or translation-related) task.
\end{abstract}

MOTS-CLÉS/KEYWORDS

hyper-textuality, multi-modality, publicity, translation studies

\section{Introduction}

Much good work on Translation Studies has concentrated on the verbal text. But the communicative messages we are exposed to everyday have always been multi-modal, as Kress and Van Leeuwen (1998: 186) explain. Nevertheless, in our postmodern world, the multi-modal nature of texts is being exploited to the maximum. And advertising is a clear example of this. Bueno (2000: 28) describes advertising as:

Publicidad es un tipo de comunicación que pretende decidir o cambiar la opinión sobre las cosas y la acción de sus receptores por medio de unas técnicas que actúan sobre el intelecto

[Advertising is a type of communication that seeks to determine or to change the receiver's opinions and actions using techniques that act upon the intellect.] 
Advertising is everywhere. It travels on public transport; it is stuck on our fridges and invades our homes via different types of media. In 1972, John Berger noted that consumers saw "hundreds of publicity images everyday." But that was in 1972. Jean Kilbourne (1999) states that in 1999 "the average American is exposed to over 3,000 advertisements a day and watches three year's worth of television ads over the course of a lifetime". Frédéric Beigbeder (2000: 57) remarks that we are all bombarded with an average of 4,000 advertising messages a day. Ramonet (2003: 72) laments the fact that:

Antes de alcanzar la edad de doce años, un niño habrá visto, en Francia, unos 100.000 anuncios que, subrepticiamente, van a contribuir a interiorizar las normas ideológicas dominantes. Y enseñarle criterios consensuales de lo bello, el bien, lo justo y lo verdadero; es decir, los cuatro valores morales sobre los cuales para siempre se edificará su visión moral y estética del mundo.

[By the age of twelve, a child in France will have seen 100,000 ads. This is going to contribute to the child's unconscious assimilation of dominant, ideological norms and teach that child widely accepted criteria about beauty, the common welfare, justice and the truth; that is, the four moral values upon which to build a moral and aesthetic view of the world.]

This is the crux of the matter. The multi-modality that characterizes texts, like advertisements, is carefully designed to make ads more appealing and luring not only so that consumers buy the products offered by the ad but mainly, as Klein (2000) maintains, so that they accept certain established ways of life and, ultimately, unchallenged ideologies

According to Sue Thomas (2004: 54), there are three different reading positions that can be adopted when dealing with these multi-layered products:

1. The "preferred" "authoritative" reading, where receivers "adopt the reading privileged by the discourse." (Thomas 2004: 54)

2. The negotiated position, "where the reader 'recognizes as appropriate the legitimacy of the preferred definitions, but identifies certain discrepancies (...) within a specific situational context' (Allen 1998: 115, in Thomas 2004: 54)

3. The resisting stance, where "the authority of the preferred reading is challenged and resisted." (Thomas 2004: 54)

Thomas (2004), like Kress and Van Leeuwen earlier (1998), stresses the urgency of a basic framework that may help us consciously decide on the position we want to adopt when dealing with multi-modality.

Drawing on Vidal's (1998) Foucauldian proposal, Calzada Pérez (2001) advocates a framework with three main (somewhat conflating) analytical stages that are here clearly differentiated for the sake of academic clarity:

a. An archeology of knowledge, which helps analysts to describe the object of study;

b. A genealogy of power, which seeks to explain the potential ideological causes and effects of the objects described; and

c. An ethical stance, which results both from previous descriptive and explanatory attempts.

Calzada Pérez (2001) maintains that there are various ways to put this general framework into more detailed practice. Calzada Pérez (2003) illustrates such practice by using a basic semiotic toolkit to describe and explain ads. The present paper, for its part, discusses the issues of multi-modality and hypertextuality (section 2). It puts forward a purely descriptive model, which is applied to original and translated (cross-cultural) advertisements in English and Spanish (sections 3 and 4). This time potential explanations on the material discussed are left to the reader and the discussion is kept at a descriptive level only for reasons that will be explained in due course. 


\section{Text, Image, and the Internet: Some theoretical considerations}

As part of their approach to the study of verbal texts and genres, scholars such as Van Leeuwen (1993) or Gastil (1992), to name but a few, have sought to identify a series of textural/tangible items (e.g. "speech acts" in the case of the former; lexicon, grammar, rhetorical structures and conversational tactics, in the case of the latter) which will ultimately help researchers identify the main socio-textual (discoursal and generic features of a verbal text). This of course rings a bell in translation studies, since Hatim and Mason, already in 1990 (and indeed before), were already advocating the study of text pragmatics and semiotics through focalization on textural units (and vice versa). Hence, following functional approaches to the study of language, and at the risk of simplifying much more elaborate frameworks for the sake of clarity, these scholars were putting forward and implementing basic analytical frameworks such as the following:

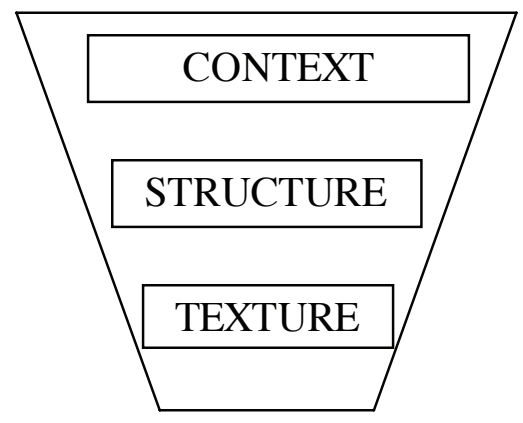

Fig. 1 A basic analytical framework

According to Askehave and Nielsen (2004), when the Internet made its appearance, this exegetic model, changed considerably. With the hypertextual products developed in tandem with the Internet, receivers were not only reading with Thomas' (2003) three potential positions; they were also navigating. In a working paper (on the Internet), Askehave and Nielsen (2004) present a new model to analyse "Web-mediated genres" that takes into account the Internet's hypertextuality:

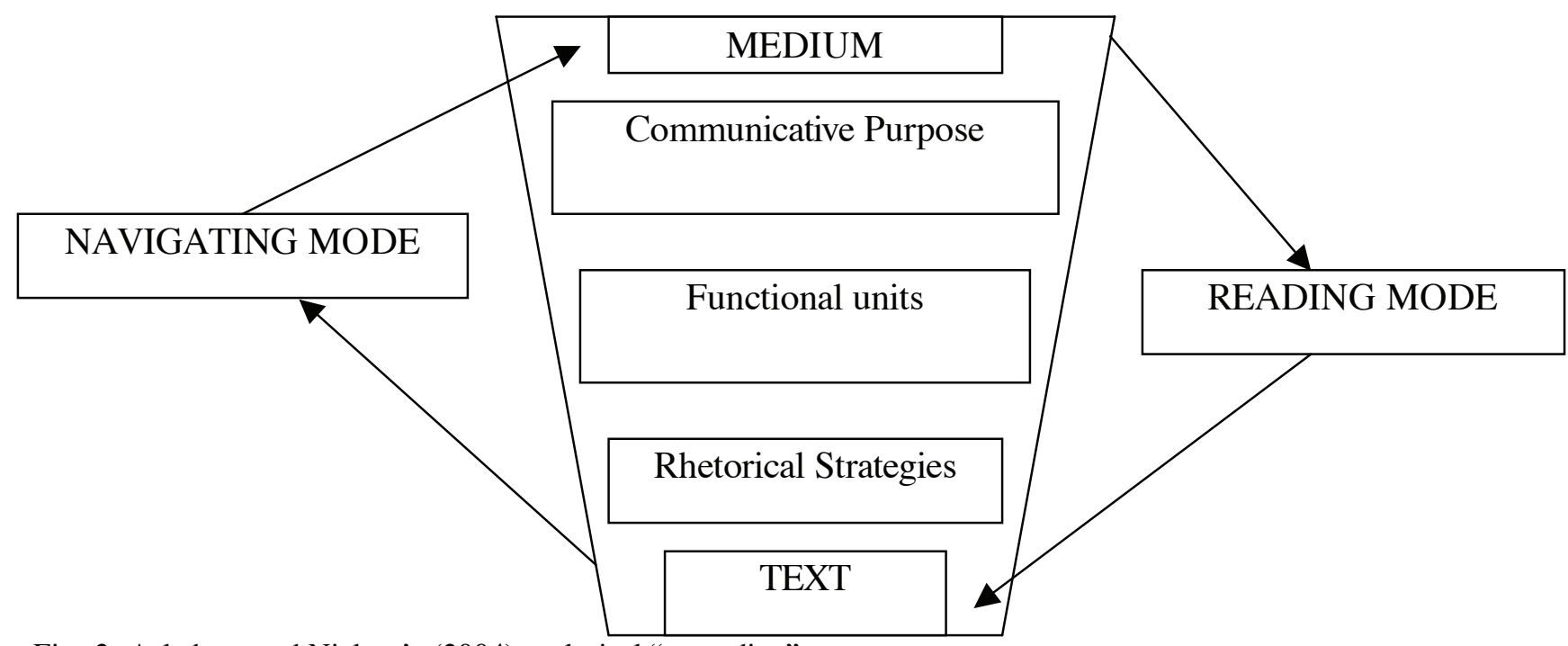

Fig. 2. Askehave and Nielsen's (2004) analytical "upgrading"

Askehave and Nielsen (2004) suggest that, when studying web-mediated genres, researchers are to take into consideration that web pages are both texts and media or gateways to further information 
(i.e. further texts/gateways). With regard to the textual facet of web pages, they reproduce the behaviour of traditional genres. Thus:

1. The genre's communicative purpose or rationale triggers

2. A particular text structure [i.e. functional units called "moves", typically consisting of so-called stages or steps]. According to Martin (1992: 443), this structure is tracked down with the help of "titles, sub-titles, headings and subheadings" and is ultimately realized by

3. Rhetorical strategies pertaining to form

However, Askehave and Nielsen (2004), expand this model to incorporate the navigating mode, in which, basically, they focus on a new type of hypertextual functional unit - the hyper-link.

"A link", according to Askehave and Nielsen (2004: 25), may be defined as "a clickable object (...) which allows the navigator to go from one place to another on a webpage or website." Both researchers put together a fairly exhaustive descriptive model for links, which they classify into structural links "to organize the information on the website hierarchically" and associative links which tie together what the web master sees as similar or related pieces of information.

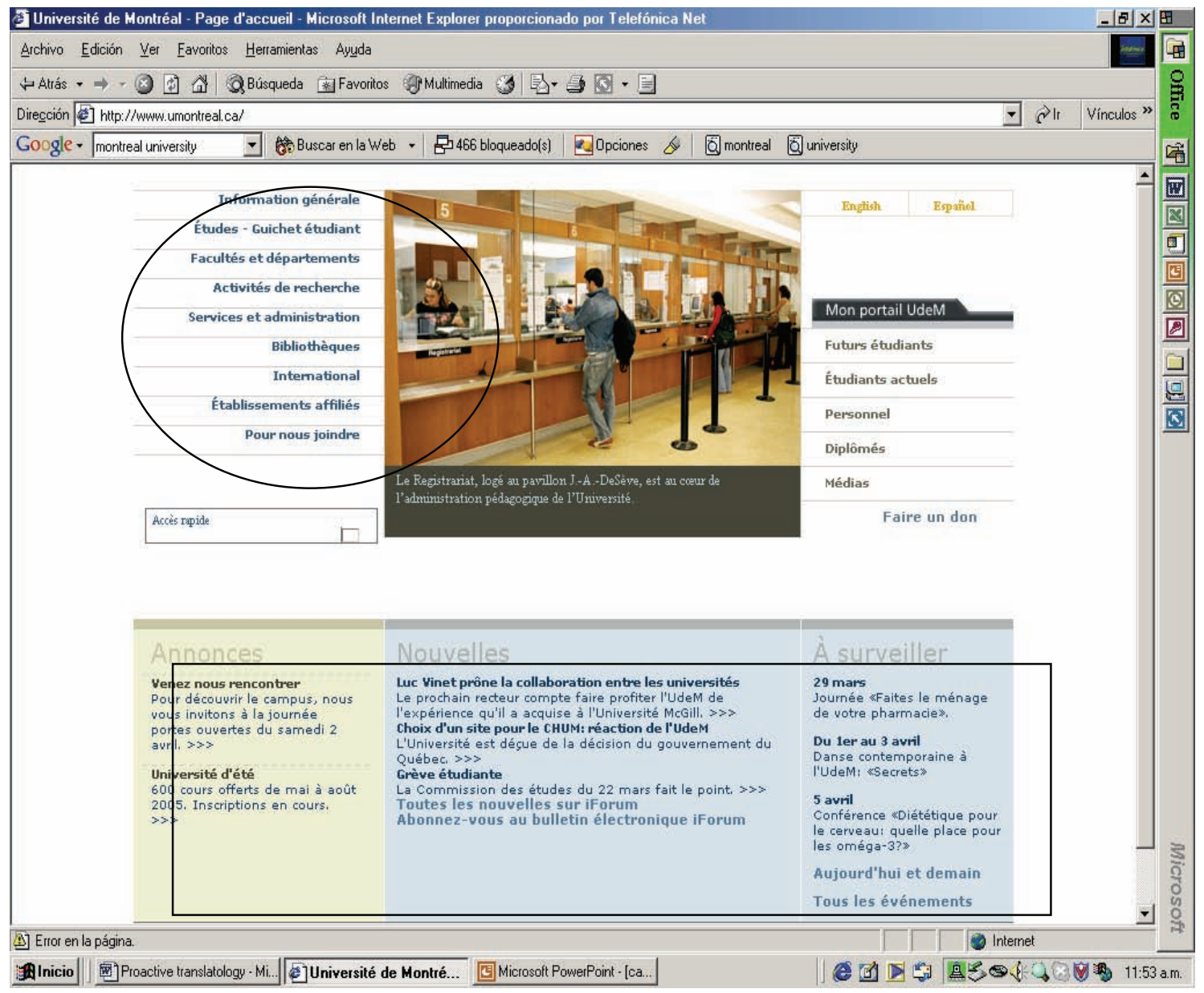

Fig. 3. Structural links (in the circled area) and associative links (in the highlighted box)

Askehave and Nielsen (2004) are particularly concerned with "the relationship established between the two chunks of information being connected" through the links. They call the first "chunk" (i.e. the textual point of entry) the "node". And they label the second "chunk" (i.e. the textual 
point of destination) as the "anchor". In fact, these researchers have created a whole typology of linking relationships:

1.Descriptive: which, in turn, may be explorative (when the anchor provides details about the properties and parts of the node) and expository (when the anchor presents the development of a procedure announced in the node). All structural links are only descriptive. Associative links may be descriptive but they may also be one of the following:

2. Narrative: When the anchor tells a story about the node, with its "initial situation (or orientation)", its "conflict (or complication)" and its "solution (or resolution)." (Askehave and Nielsen, 2004: 28)

3. Argumentative: When anchor and node serve to argue in favour or against a proposition

4. Explicative: When node and anchor include two elements: effect and cause representing a why-because relation. Explicative links differ from argumentative links one in that in the latter no judgment is being passed.

5. Dialogical: When node and anchor serve to establish a conversation with a turn-taking approach.

This textual/hypertextual (but nonetheless predominantly verbal) model still needs to be refined to account for the visual components of texts. Kress and Van Leeuwen (1998) and "An

Introduction to the Grammar of Visual Design" (referred to below as the GVD), a study carried out within the framework of Australian Government's Quality Teacher Program, constitute excellent reference resources for analyzing West-related design.

The visual component of contemporary texts is acquiring burgeoning importance and merits detailed analysis. For Kress and Van Leeuwen (1998: 188), this entails delving into "three signifying systems, all serving to structure the text":

a. Information value

b. Salience

c. Framing

Information value depends upon "the placement of elements in a text's layout" (Kress and Van Leeuwen 1998, 188). In the West, when visual text components are displayed in a left vs. right arrangement, those elements on the left represent the Given and those on the right, the New. If, however, the predominant layout adopts a top-down structure, the upper constituents evoke the Ideal (i.e. abstract or generalized concepts), whereas the lower ones point to the Real (i.e. detailed pieces of information). The visual layout may also revolve around the Centre (i.e. the most decisive piece of information) while the Margins are minoritised constituents of secondary importance. It is interesting to note that Kress and Van Leeuwen (1998: 196) claim that Centre/Margins layouts are not very popular in Western cultures at the moment, whereas they are employed in Eastern Cultures possibly due to the fundamental role the Centre plays in Confucian-related cultures. Other potential layouts include the triptych, which may structure components according to importance, chronology or some other kind of relationship.

Salience refers to the manner in which elements are presented to the readers so that they are noticed more or less easily. It depends on a variety of factors such as size, sharpness of focus (...) tonal contrast (...) colour contrast, weight of object - "elements not only become 'heavier' as they move towards the top but also appear 'heavier' the further they are moved towards the left, due to an asymmetry in the visual field" (Kress and Van Leeuwen 1998: 200)-, perspective (foreground objects are more salient than background objects) and even cultural factors (such as the use of symbols, etc.).

Lighting and colour may have other consequences, according to the GVD. While shadows may suggest that something is being concealed, bright light can produce a sense of hope and a soft light may contribute to creating a romantic atmosphere. Colours, for their part, are also used in order to create certain moods. Below is a colour table included in "An Introduction to the Grammar of Visual Design" especially related to Western cultures: 


\begin{tabular}{|l|l|}
\hline Blue & $\begin{array}{l}\text { Peace, tranquillity, truth, dignity, power, melancholy, coolness, heaviness. } \\
\text { Regarded as being therapeutic. } \\
\text { Happiness, cheerfulness. Can denote caution, decay, and sickness. } \\
\text { Wed }\end{array}$ \\
Wreen & $\begin{array}{l}\text { an accent colour, it can promote expectations and quick decision-making. } \\
\text { Growth, fertility, health, cheerfulness, vegetation, money. Signifies life, new } \\
\text { growth, energy and faith. } \\
\text { Cool detachment, bleakness, and lack of intensity. } \\
\text { Wealth, royalty, sophistication, intelligence. Also the colour of passion and love. }\end{array}$ \\
Purple & $\begin{array}{l}\text { Death, rebellion, strength and evil. Associated with the supernatural, it can also } \\
\text { suggest inner strength and determination, as well as power and formality. }\end{array}$ \\
Black & $\begin{array}{l}\text { Purity, chastity and cleanliness. } \\
\text { Nostalgia, seriousness, truth, detachment. } \\
\text { Black and white }\end{array}$ \\
Brown & $\begin{array}{l}\text { Credibility, stability, and neutrality. } \\
\text { Warmth, strength of personality. Associated with autumn, it also has broad } \\
\text { Oppeal. }\end{array}$ \\
\hline
\end{tabular}

Fig. 4 Colour table from the GVD

According to Kress and Van Leeuwen (1998: 203), framing refers to the way in which visual components interact with each other and with consumers. For Kress and Van Leeuwen (1998: 203), visual constituents themselves may be connected or disconnected. Some elements may be strongly connected through repetition of forms and colours for example. Alternatively, they may be strongly disconnected through the use of framelines, discontinuities of colour or simply white spaces. Indeed, for Kress and Van Leeuwen, framing seems to be a matter of degree. According to the GVD, constituents may be also connected or disconnected to consumers in weaker or stronger ways. Intimate distance is captured by a shot of the face or head; close personal distance with a portrayal of the head and the shoulders; far personal distances is pictured by a figure from the waist. Far close social distance is conveyed by whole figures while far social distance is depicted by the framing of groups of people. Incidentally, the relationship between constituents and consumers is also marked by vertical and horizontal axes. The former represents power so that when constituents are viewed from above, consumers are in a position of power, when they are seen from below, constituents assume the power position; if the angle is straight, the relation is that of equality. The horizontal axis depicts involvement with the consumer. The more horizontal the constituents, the greater the involvement with the consumer.

I will now apply these theoretical assumptions to the description of a series of ads. In section 3 , I will focus on verbal and visual ads appearing in magazines. Here I will draw mainly on the textual "reading model" developed by Askehave and Nielsen's (2004) and also on Kress and Van Leeuwen's (1998) critical suggestions on visual elements. In section 4, I will concentrate on webads for which Askehave and Nielsen's (2004) navigating links will prove particularly helpful.

\section{Magazine ads}

\subsection{An Ideal (Monoglossic) Hepburn vs. the Same (Multilingual) Myth}

As was seen above, according to Askehave and Nielsen (2004), texts' communicative purpose is realized by structural functional units (called moves), which, in turn, are encoded into specific textural features. The latter will be displayed according to particular layouts that may be carefully analysed drawing on Kress and Van Leeuwen (1998). 
Ad 1 is the English version of an advertisement for a Swiss-made Longines watch called Dolce Vita.

Being very cautious, one can only claim that Ad 1's communicative purpose is to entice consumers to go and buy this Longines watch. The structural moves the ad uses in order to achieve this purpose are (from top to bottom): logo (including brand and slogan of the company), Picture 1, Picture 2 (including product and name) and a footer (with technical details about the product). These structural moves are encoded into the textural features described below. Regarding information value, the ad (targeting a Western English-speaking audience) is clearly arranged in a top-bottom structure. The top (representing the Ideal -i.e. abstract, general notions) is occupied by the brand's logo and, especially, by a very stylish Audrey Hepburn. The bottom part of the ad, representing the Real -i.e. detailed information-, displays the watch's shape together with specific technical details about it. At the Centre of the ad (a main focus of attention), consumers may read the following message in English: "Elegance is an attitude". Regarding salience, lighting and colour, the whole ad is in black and white, which means "Nostalgia, seriousness, truth and detachment" (see Fig. 4 above). In fact, it would not be far-fetched to claim that these colours may also be associated with Elegance (the motto of the ad). Hepburn's brightness stands out against a dark, grayish background; the watch, for its part, is surrounded by strong lighting. As far as framing is concerned, Hepburn and the Longines Dolce Vita watch are clearly disconnected from each other in the sense that they are both encapsulated in different black/white boxes. Nevertheless, there is enough hints to suggest a clear connection between them. Hepburn's figure blends with the watch's shape along a perfect vertical axis, and both pictures (Hepburn's and the watch's) are literally linked by the Ad's verbal message (i.e. "Elegance is an attitude", in the black box). With such clear continuity patterns, it would not be illogical to claim that the watch is associated with Elegance which ultimately refers to the Ideal Audrey Hepburn. It is also interesting to notice that from her upper position, Hepburn acquires the power role vis-a-vis the consumer. It also seems relevant to point to the fact that the famous actress stands at a "far close social distance" from the consumer.

\section{Ad 2 is the Spanish version of Longines's Dolce Vita Watch.}

The Spanish version of the ad has exactly the same communicative purpose as its English counterpart, that is, that of sending the consumer straight to the shop to buy the product. The structural moves the ad uses are the same as those in English except that the English technical details about the product (at the bottom) have disappeared. With only one element missing, however, the ad's textural layout differs tremendously from that of the English version. Regarding information value, the predominant arrangement this time (for a Western Spanish-speaking consumer) is that of Left (for The Given) vs. Right (for the New). According to Kress and Van Leeuwen (1998), now Longines sells its watch by sending the message that Hepburn is an already well-known ("cherished" but "given" nonetheless) myth while the watch is being portrayed as the radically new item of information. The texts' message in the Spanish ad remains in English (which -by the way- elicits comments about tolerance to "foreign" verbal signs) and is not placed inside Hepburn's black box only but is shared between both black and white boxes. Also, Longines' logo is not "ideal" any longer since it drops from its English top left location to the Spanish "real" bottom left hand corner. Regarding salience, colour and lighting, Ad 1 and 2 are virtually the same. Regarding framing, however, important differences emerge again. On the one hand, Hepburn and the Watch are again disconnected by their black and white boxes, although also connected by the mimesis of Hepburn's figure and the watch's shape. However, this parallelism does not take place along a perfect vertical axis. Verticality is interrupted and with it Hepburn acquires a less powerful position vis-à-vis the consumer. In fact, even the close social distance that separates ad and receiver seems slightly smaller in ad 2.

So as we may see here, both Askehave and Nielsen (2004) and Kress and Van Leeuwen (1998) help us describe the different mechanisms used by Longines to advertise for Western (English and Spanish) consumers. With comparable communicative purposes and similar structural 
moves, the Spanish and English ads expose consumers to very different texture that may (consciously or unconsciously) end up sending different messages to different audiences.

\subsection{Women as forbidden targets of desire}

Ad 3 is the English version of an advertisement for Moschino's Parfum L'Eau.

Ad 3's communicative purpose is to convince Western (English-speaking) consumers to buy Moschino's product. For this purpose it uses as structural moves the Moshino Parfum brand, a slogan which bears the name of the product ("L'Eau", "CheapandChic", "The Funny Side of Myself") and an Image. The textural realization of purpose and moves is as follows. As far as information value is concerned, the ad adopts a pre-eminently Central layout where the image of a naked female subject holding something like a lollipop occupies the dominant textual position. A bottle of the product advertised may be seen below, by the central subject. As marginal elements, for Western (English-speaking) consumers are the name of the brand (in the top left hand corner, in an "Ideal" position) and the verbal message below in a "Real" location vis-à-vis the name of the brand. Regarding salience, colour and lighting, the undoubtedly predominant constituent is that of the funny lollipop (possibly depicting the message - "the funny side of myself") which is largely illuminated in the forefront. Behind stands the naked woman in blue and grayish tones. According to the GVD (see fig. 4 above), blue is the colour for "peace, tranquility, dignity, power, melancholy, coolness, heaviness", and is "regarded as being therapeutic". In fact, the whole visual composition may be considered to represent a relatively cool, calm dignified woman who has nevertheless a funny rebellious side depicted by the lollipop. The latter is pinkish, a very similar colour to that of the perfume's top. As far as framing is concerned, lollipop, perfume and the upper part of the background are connected due to their similar pinkish tones, in the same manner in which the bluish woman blends in with the lower part of the background, also in blue. The naked woman is gazing straight into the consumer's eyes establishing with him or her some sort of undecipherable/mysterious bond.

Ad 4, is the Spanish version of the previous ad in English. Communicative purpose (i.e. seducing the Western, Spanish-speaking consumer into buying Moschino's L'Eau) and structural moves (logo, message and image) coincide with English Ad 3. However, it is again the textural realisation of the ad's structure that differs considerably from its English "equivalent". With regard to information value, Ad 4 is also a basically Central composition. However, this time the Centre is occupied by the funny lollipop while the naked woman holding it disappears from the picture completely. The English ad's sexual suggestiveness is removed (possibly censored) from the Spanish version. The lollipop, in turn, does not resemble a lollipop any longer but adopts the form of a cheeky funny face "sucking" on Moschino's perfume (possibly a compensation for the previous loss of sexual innuendo). Moschino's Parfum logo stays on the "Ideal" top left corner (as in the English version) but the message ("L'Eau. CheapandChic. The Funny Side of Myself"), in English (again a brief reference to multilinguistic tolerance in the Spanish-speaking world seems pertinent), is relegated to the very bottom, left hand corner in a Real position (like in the English ad) only further away from the logo than in the English ad. As for salience, colours and lighting, the prominent face, in a predominantly pinkish tone, blends in with the pinkish upper part of the background, although the face shows bluish nuances that resemble the lower part of the background. There is no clear opposition between the woman's calm, cool, melancholic nature and the lollipop's funny appearance. Here it is the face itself which becomes bluish and pinkish (i.e. calm, melancholic and funny at the same time). The emotions that are to be conveyed to the consumer are personified in an inanimate object whereas in the English ad they are assigned to an animate woman-object. Regarding framing, face and background are closely connected through colour. Whereas the naked woman is looking at the consumer in a mysterious manner (establishing a relationship with him or her) the Spanish funny face closes its eyes and with them all possible contact with the receiver. 
Even though similarity seems to obtain between Ads 3 and 4 at the level of communicative purpose and structural moves, striking differences are identified at the textural level.

\section{Web-ad Campaigns: Linking Multinationals' Prejudices.}

Companies may also use the new hypertextual media to advertise their own products. Among the Internet's main advantages, Naphtali and Peng (Online), in a paper written for the Internet Society's seventh annual conference (INET'97), list the following:

1. Its interactivity, immediacy, limitless and three-dimensional space;

2. The relatively low costs of setting up web-sites;

3. The absence of paper and delivery costs;

4. The presence of an increasing market of relatively well-off and educated consumers;

5 . The possibility for the exchange of ideas worldwide;

6 . The easy incorporation of enticing multimedia elements.

However, in spite of all these advantages the same authors admit that "Except for multinational companies such as Coca-Cola and McDonald's, Erlindson says that advertising will have a local focus".

Let us see what happens when we examine ads on the web produced by two of the largest US multinationals in the world, McDonald's and Coca-Cola's, using the proposals put forth by Askehave and Nielsen's (2004).

\subsection{McDonald's' description of the world}

McDonald has web-pages for 59 countries in the world on its main web-site (www.mcdonalds.com) with links to "McDonald's world countries". These links are, in Askehave and Nielsen's (2004) terminology, "structural" - since they structure the way pages are organisedand therefore descriptive. Consequently, the viewer expects a connection between these nodes (i.e. names for countries) and the way McDonald's sees or presents these countries to consumers.

If we click on North American countries ${ }^{1}$, such as Canada, McDonald's offers a very colourful and appetizing page. Briefly, the page has a top-bottom arrangement, where the "Ideal" locus is occupied by a McDonald's Beef and Provolone Burger, whereas "Reality" gives more detailed information about Mcdonald's "Our foods", "Careers", "About us" and "Community Commitment". The default web-page is in English, although it is possible to access the French site.

If we click on European countries, such as Spain, the destined anchor is again a colourful, appealing dynamic (i.e. moving) page with a top vs. down layout. The "Ideal" position is prominently occupied by McDonald's burgers and an inviting and challenging question (aiming to deconstruct negative myths about their products): Have you ever wondered what our burgers are made of?" Further up, consumers may find information about the Company (qué tomo hoy / what shall I have today; zona infantil / children's area; nutrición /nutrition or our food; información corporative / information about the company; localiza un restaurante / find a restaurant and prensa / press). At the "Real" location there are more details about McDonald's new products, news and so on. The whole page is in Spanish with no possibility to consult sites in the other official languages of Spain (such as Catalan, Galician or Basque).

The same thing happens if one clicks on booming Asian economies, such as Japan, on heavily Westernised Australasian markets (such as Australia), or on large Latin American countries such as Mexico.

If one, however, enters smaller (Underdeveloped/Developing/Third World?) Latin American countries, McDonald's "anchors" describe countries - "nodes"- in a much less colourful manner. In fact, all of them are homogenized in one of two very plain standard formats with no attractive colours, no movement and no sophisticated visual design. The first of these "plain" formats may be represented by McDonald's site for Guatemala (http://www.mcdonalds.com/countries/guatemala.html). The site is a white A4 page with the 
following headings in English: "Welcome to McDonald's Guatemala", "Unique restaurant", "Community involvement", "Corporate Office". No possibility for other languages, including official Spanish, is envisaged. The page clearly targets Guatemalan consumers who are seeking further information about McDonald's but who will have to make do with simple (and cheap) stimulus.

The second of the two "plain" formats used by McDonald's for minoritised word regions may be represented by pages for other Latin American countries, such as Uruguay (http://www.mcdonalds.com/countries/uruguay.html). These countries are smaller and less influential than Mexico, for instance, but their economies may be seen as more solid than those of countries like Guatemala. Under the heading of "Welcome to McDonald's Uruguay", the page is a tourist brochure devoted to locating Uruguay on the map and introducing it to potential consumers who are, obviously, not Uruguayan themselves but probably Western English speakers wishing to travel to this Latin American country. It gives the impression that, for McDonald's, countries with this format are probably safer and more worthy of a visit than countries with the previous Guatemalan-style web site. Finally, the page includes a link to consult the same information in Spanish.

McDonald's pages for Arab-speaking countries are all of the first "plain" type and none of them offers the possibility of consulting pages in Arabic. Arabic has completely disappeared from McDonald's hypertextual world.

Except for South Africa, McDonald's has no pages whatsoever for Sub-Saharan Africa, which is, in effect, non-existent for this big US multinational.

\subsection{Coca-Cola spreads the news in Africa}

According to Tham and Peng (Online), Coca Cola is the other major multinational that seems to benefit from the cyberspace. And unlike McDonald's, for Coca Cola, Africa does exist. As we may see from Coca Cola's official web-site (www.cocacola.com), Africa is in fact depicted as nothing but a huge container for Coca Cola bottles (see http://www.africa.coca-cola.com/).

There are similarities, however, between Coca-Cola and McDonald's. Like McDonald's, Coca Cola has imaginative campaigns for Western, Westernised or booming economies (e.g. CocaCola UK at www.coca-cola.co.uk). However, once in Africa, Coca Cola adopts the same homogenizing and simplistic campaign as McDonald's has launched for underdeveloped/developing/Third World countries. All Coca Cola web sites for African countries follow exactly the same pattern (or comprises exactly the same "structural moves", using Functional Grammar approaches): As can be seen from Coca Cola's web site for Egypt (at www.cocacola.com and then clicking on Egypt), the recurrent moves are: the Coca-Cola Company logo, a series of structural links, a welcoming message ("Welcome to Egypt"), associative links (regarding "news", "finding a job for Coca Cola", or going back "home" (to www.cocacola.com).

Since, in the previous section, we already analysed structural links for McDonald's, we are now clicking on a typical Coca Cola associative link in African pages: "News. The latest News brought to you by our media partners in Africa". The linking node seems to anticipate a narrative anchor, where pieces of information about the world at large and about the African "region" in particular might be discussed. The anchor could, therefore, be expected to include heated discussions about current affairs, political events related to Egypt, etc. However once we click on the departing node, the narrative anchor we find only leads us further away from our expectations. Coca Cola's prominent item of news ("by Coca Cola media partners in Africa") reads: WFP [World Food Programme] promotes education of the girl child in Egypt". All other pieces of news on the same page are also about charity programmes in Africa. One can only conclude that the narrative associative link selected by Coca Cola for the Egyptian site perpetuates a long-standing Western prejudice that considers Africa as a place for the First World to promote its charities.

Web sites for other African countries (see Cameroon, for instance) confirm this conclusion about associative links. This is indeed Coca Cola's dominant rule. It would appear that, for Coca 
Cola, Africa is either a huge container for Coca Cola bottles or a massive swathe of disasters where the West can and does "laundry its conscience".

\section{Conclusion}

Today's cross-cultural communication cannot be understood without taking into account phenomena such as multi-modality and hypertextuality. The degree to which current texts rely on these phenomena is not only significant but also on the rise. Facing both multi-modality and hypertextuality, translators and translation studies scholars have at least two options. They may maintain the normative definition of translation as a transfer of written words/texts between cultures. Alternatively, they may fight to expand the definition of translation to incorporate these and other inter-semiotic issues, which are by no means marginal. I want to position myself within the second group. After all, images need translating as much as words and cyberspace is nothing if not a huge meeting point which provides information that is constantly translated back and forth.

The advertisements discussed in this paper show that by connecting texture, structure and context, in the way Askehave and Nielsen (2004) recommend, and by analysing information value, salience and framing, with the help of Kress and Van Leeuwen (1998), translators may successfully go beyond the written word/text. When they do so, they are unexpectedly brought face to face with yet more of the ideological pressures of the globalised world, in which texture and structure are put to the service of certain ideological causes with which translators may or may not agree. For example, the disappearance of the naked woman in Moschino's ad has clear ideological consequences. The structural arrangement of McDonald's web-pages for Western and minoritised countries undoubtedly has ideological implications. The associative links used by Coca Cola to publish the(ir) "news" and reinforce Western stereotypes of Africa have again indisputable ideological results. Translators and translation studies scholars may decide that these communicative messages are not their responsibility but that of other professions. They may alternatively decide that, as cross-cultural communication experts, they may legitimately contribute to translating such messages. Whatever their preferred option, as Maria Tymoczko has argued, translators and scholars cannot avoid making the choice. They are never in between and their choice inevitably helps reinforce or deconstruct some of today's (overt or hidden) agendas.

Multi-modality and hypertextuality may be both described and explained. The present paper is limited, as much as possible, to description. There are two reasons for this:

1. More sociological data (than that discussed in this paper) would be required for in-depth explanations.

2. Descriptions are fundamental bases upon which audiences can generate their own explanations.

However, explanatory work on multi-modality and hypertextuality is required and the present paper calls for further research along these lines. Finally, the (normative or expanded) definition of translation depends heavily on our educational systems. At the end of the day, it is up to trainers (among other systemic forces) to pass on metatheoretical attitudes towards the discipline itself and the (detached or engaging) role it is to play in our societies.

\section{NOTES}

1.The specific web-pages discussed were consulted on $23^{\text {rd }}$ February, 2005. 


\section{REFERENCES}

An Introduction to the Grammar of Visual Design (2002): Australian Government Quality Teacher Program, Secondary English LIG. Askehave, I. and NiElsen A. E. (2004): "Web-Mediated Genres- A Challenge to Traditional Genre Theory", in Working Paper 6, 〈http://www.asb.dk/centres/cbcom/publikationer/workingpapers/wp2004.aspx〉

BASSNET-MCGuiRE, S. (1988): Translation Studies, London and New York, Routledge. Bueno, A. (2000): Publicidad y traducción, Soria, Vertere. [ Coll. "Monográficos de la Revista Hermeneus, 2 , Diputación de Soria"]

CAlZAdA PÉrez, M. (2003): "Publicidad y traducción: el robo de mitos y contramitos en un mundo globalizado", in Lingüística Antverpiensia, 2, p. 283-300.

De CAmpos, H. (1986): “The rule of Anthropophagy: Europe under the Sign of Devoration”, in Latin American Literary Review, 14-27, p. 42-60.

GASTIL, J. (1992): "Undemocratic discourse: a review of theory and research on political discourse", Discourse \& Society, 3-4, p. 469-500.

Hermans, T. (1997): "The Task of the Translator in the European Renaissance: Explorations in a Discursive Field", in BAssnett, S. (ed.): Translating Literature, Cambridge, D.S. Brewer, p. 14-40.

Kress, G. and VAn Leeuwen, T. (1998): "Front Pages: (The Critical) Analysis of Newspaper Layout", in BELL, A. and Garrett, P. (eds.): Approaches to Media Discourse, Oxford, Blackwell, p. 186-219.

MARINA, J. A. (2004): Aprender a vivir, Barcelona, Ariel.

MARTIN, J. R. (1992): English Text: System and Structure, Amsterdam, Benjamins.

MAYORAL, R. (2002): “¿Existe la teoría de la traducción?”, in Apuntes, 10-4, p. 12-3.

Tham, N. I. and Peng, F.Y., (Online): "World Wide Web Publishing: An Overview of WWW Newspapers from the United States", in 〈http://www.isoc.org/inet97/proceedings/G1/G1_3.HTM〉, Consulted on 21/03/2005, p. 1-24.

Thomas, S. (2004): "Reading Through the Basics: Towards a Visual Analysis of a Newspaper Advertisement on Education", Language and Education, 18-1, p. 53-68.

TyMOCZKO, M. (2003): "Ideology and the Position of the Translator. In What Sense is a Translator "In Between"”, in CAlZADA PÉREZ, M.(ed): A propos of Ideology: Translation Studies on Ideology - Ideologies in Translation Studies, Manchester, St. Jerome, p. 181-201.

VAN LEEUWEN, T. (1993): "Genre and field in critical discourse analysis: a synopsis", in Discourse and Society, 42, p. 193-223.

VIEIRA, E. (1999): “Liberating Calibans. Readings of Anthropofagia and Haroldo de Campos' Poetics of Transcreation", in Bassnett, S. and Trivedi, H. (eds.): Postcolonial Translation. Theory and Practice, London and New York, Routledge, p. 95-113. 
APPENDIX

Ad 1
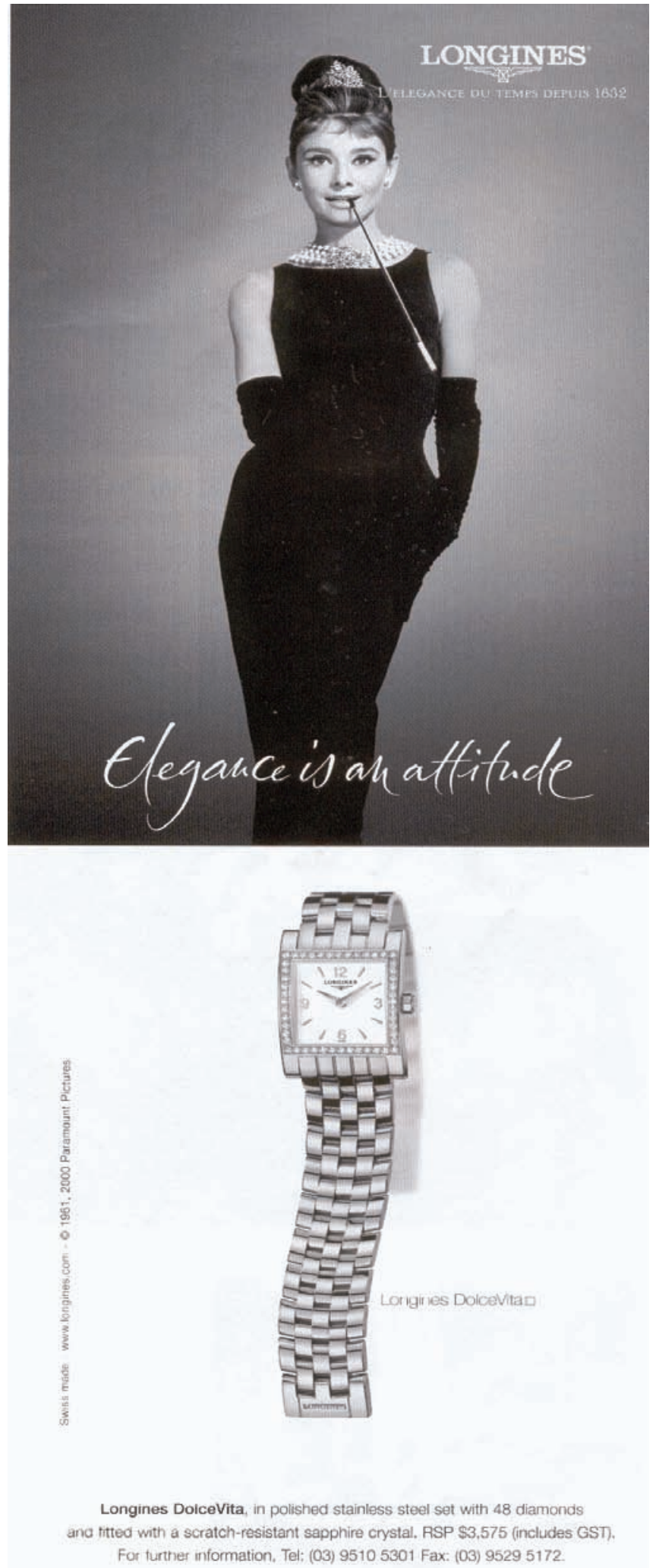
Ad 2

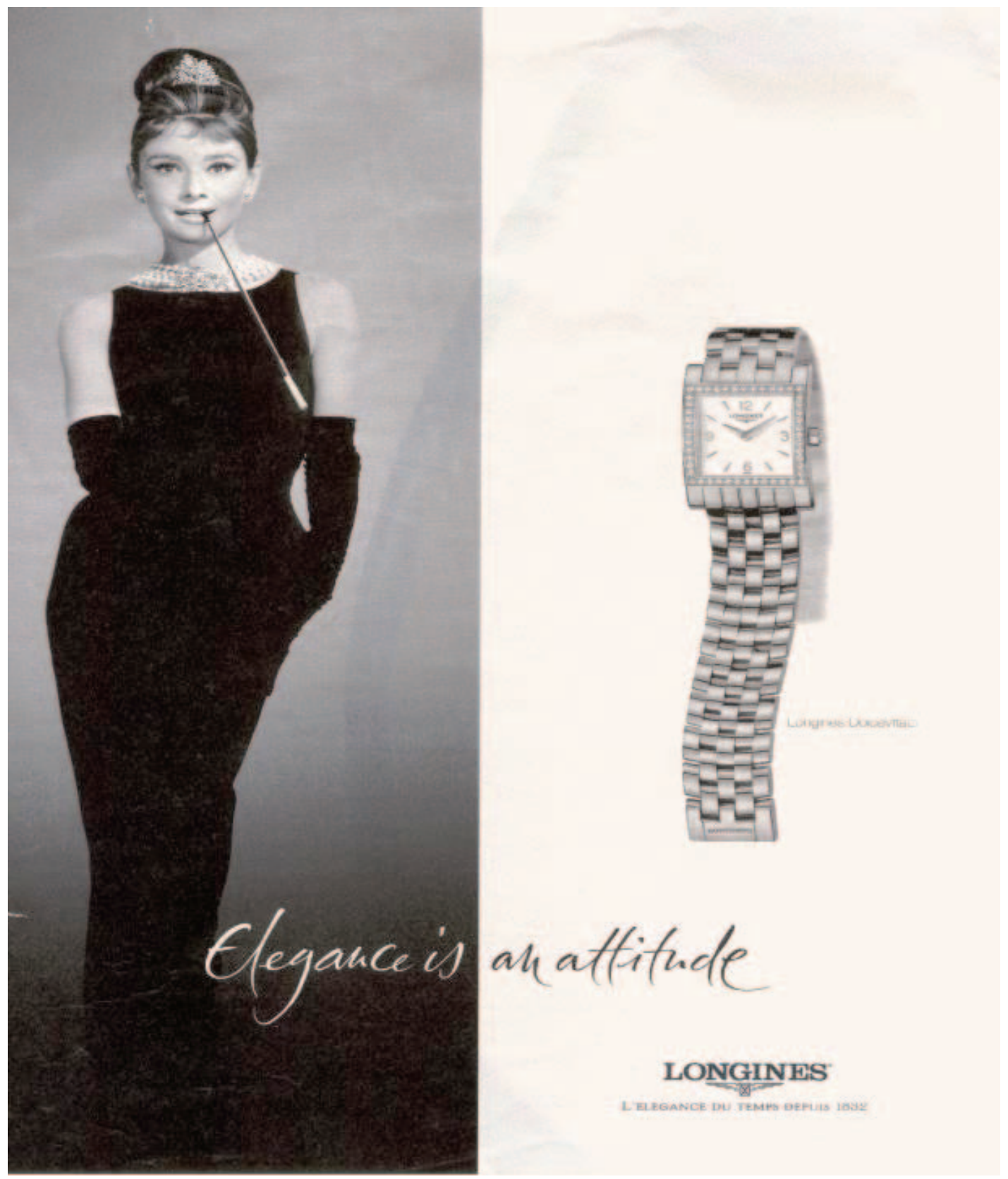


Ad3

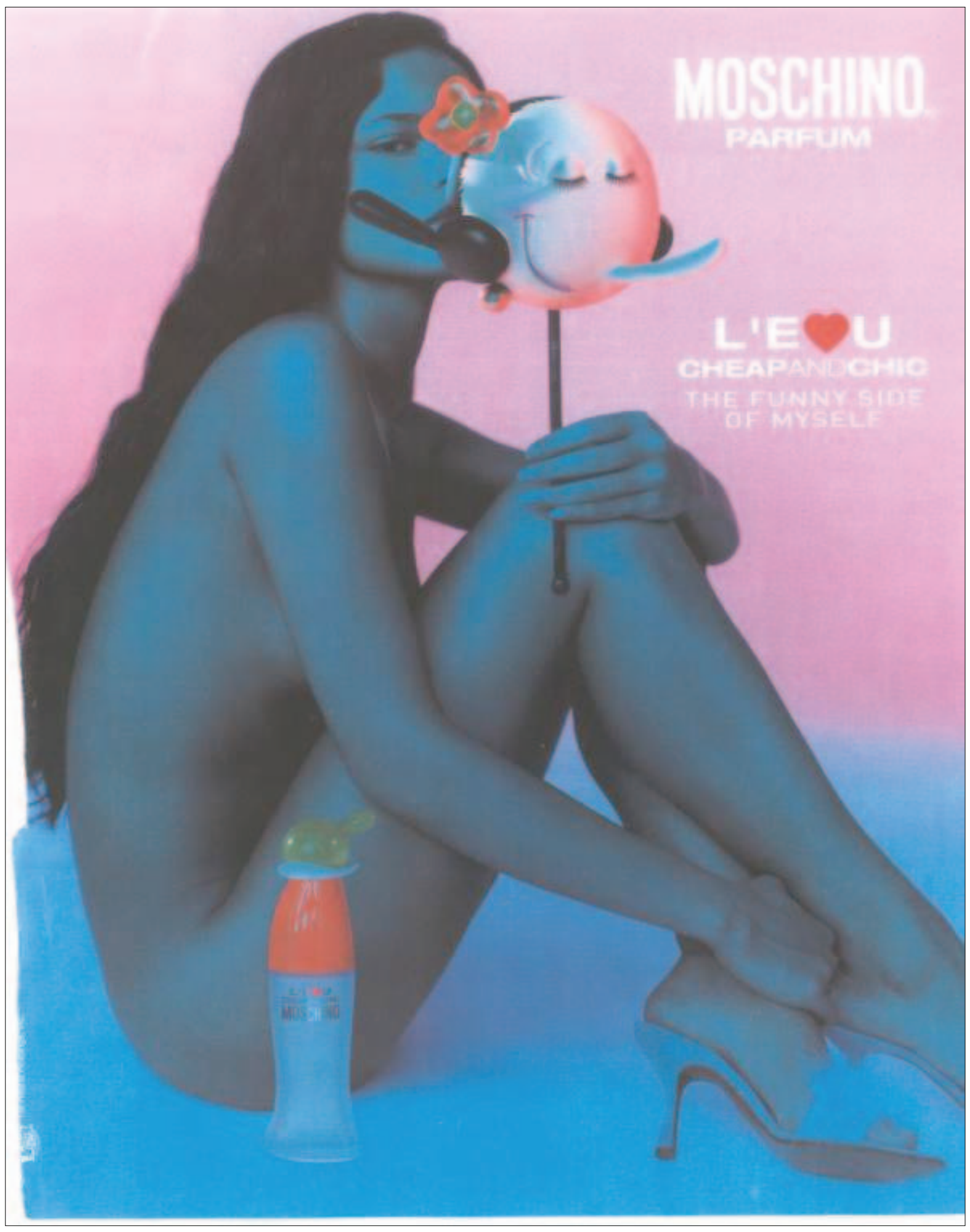


Ad 4

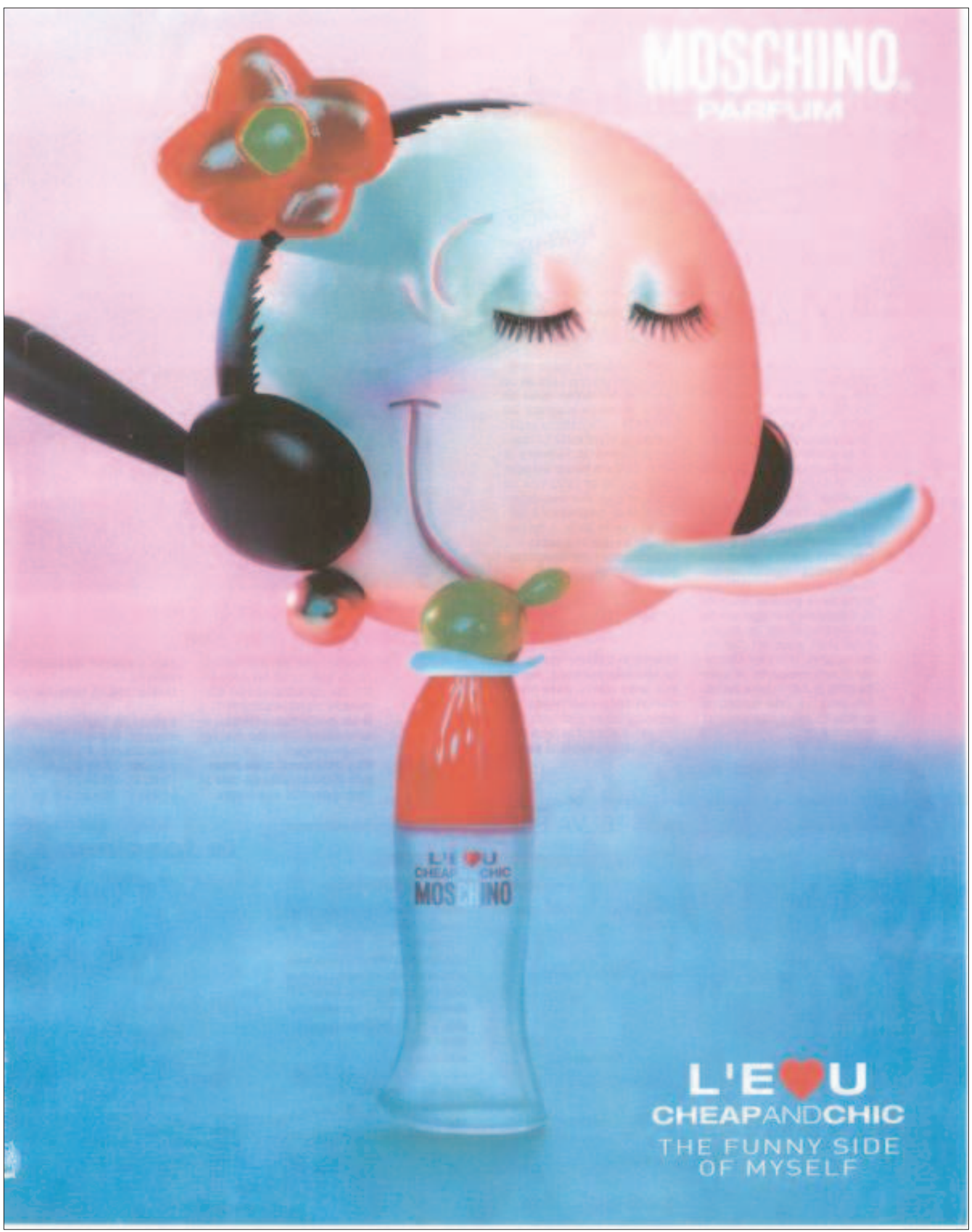

